Yahweh's Coming of Age 



\section{Yahweh's Coming of Age}

Jason Bembry

Winona Lake, Indiana

EISENBRAUNS

2011 
(C) 2011 by Eisenbrauns Inc.

All rights reserved

Printed in the United States of America

www.eisenbrauns.com

\section{Library of Congress Cataloging-in-Publication Data}

Bembry, Jason.

Yahweh's coming of age / Jason Bembry.

p. $\mathrm{cm}$.

Includes bibliographical references and indexes.

ISBN 978-1-57506-172-6 (hardback : alk. paper)

1. God (Judaism)-Age. 2. Bible. O.T.-Criticism, interpretation, etc.

I. Title.

BM610.B37 2011

296.3'112-dc22

2011008537

The paper used in this publication meets the minimum requirements of the American National Standard for Information Sciences-Permanence of Paper for Printed Library Materials, ANSI Z39.48-1984. @ ${ }^{\mathrm{TM}}$ 